decline (this is one of the complexities!). Having already defied the NMP by allowing a quota for bowheads in Alaska, the Commission would threaten the credibility of the NMP if it allowed another infraction for the sake of another small coastal whale industry, that of Japan. But if a zero quota is imposed, Japan can quite legally, under the Convention, refuse to adhere to it. That is why it was easier for the commissioners to do nothing this time.

As a small compensation for the ridiculus mus produced by the main item on the agenda, delegates were able to hear statements from the United States that the number of bowheads struck but not killed had been substantially reduced, and from Japan, Norway and South Korea justifying their refusal to abandon the cold harpoon (agreed last July) by their failure so far to come up with a satisfactory substitute. But Japan assures us that research to find a safe explosive harpoon continues vigorously.

\title{
Good News About Orang-Utans in Sarawak
}

\section{Michael Kavanagh}

Hopes that a viable population of orang-utans can be conserved in Malaysian Borneo have been given a big boost by the discovery that they are more widespread than had been expected. In August-November last year a research team, consisting of officers from the National Parks and Wildlife Office of the Sarawak Forest Department and five scientists sponsored by WWF Malaysia, surveyed the proposed Lanjak-Entimau Orang-Utan Sanctuary adjacent to the Indonesian frontier. Previous reports had led them to expect to find orangs in the southern part of the proposed sanctuary, where the terrain is most rugged and there has been least human activity, but the development of a novel survey technique showed that the apes inhabit the northern part as well.

Orangs build nests in trees both for sleeping in at night and also for daytime dozing. Sometimes a single ape will build several nests in one day. One of the forest guards discovered that many of these could be spotted from a low-flying helicopter. A systematic survey flight was organized with the aid of the Royal Malaysian Air Force and in one hour of flying, nearly a hundred were counted.

More down-to-earth reconnaissance and census walks showed that the apes are illegally hunted but it was concluded that with adequate protection, the population would increase until it reached the carrying capacity of the forest. Tentative plans to translocate orangs to Lanjak-Entimau from doomed tracts of forest elsewhere in the state were abandoned. Although the numbers of animals that would be involved in such an exercise might be very small, the disruptive effect on the resident community might be very great.

Healthy populations of other animals found during the survey included Sarawak's acrobatic lesser ape, the grey gibbon, two langurs and two macaques. Borneo has eight hornbill species of which seven were recorded in the area. Happily, they included large numbers of the bird that is Sarawak's official state emblem, the rhinoceros hornbill Buceros rhinoceros, and also the very beautiful but threatened Bulwer's pheasant Lophura bulweri.

Although Lanjak-Entimau has suffered from some shifting cultivation in the past, and the local Iban people have been free to hunt there - as long as they did not touch any protected species - the survey confirmed that the proposed sanctuary will include some excellent hill forest with 
